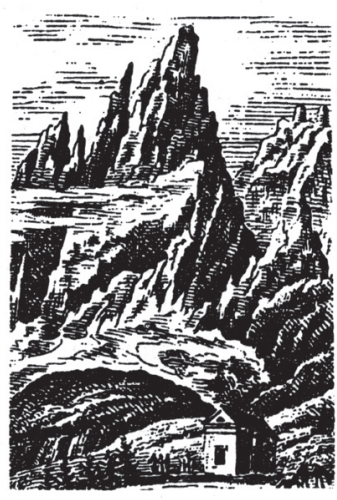

Justyna Bajda

ORCID: 0000-0001-7402-090X

Uniwersytet Wrocławski

justyna.bajda@uwr.edu.pl

DOI: 10.19195/2084-4107.12.17

\title{
W naszej letniej stolicy... Satyra Ludwika Szczepańskiego na młodopolskich turystów w Tatrach
}

Słowa-klucze: przełom XIX i XX wieku, Zakopane, letnia stolica Polski, powieść kurortowa, satyra, Ludwik Szczepański, Kazimierz Przerwa-Tetmajer

Keywords: turn of the 20th century, Zakopane, summer capital of Poland, resort novel, satire, Ludwik Szczepański, Kazimierz Przerwa-Tetmajer

\section{W naszej letniej stolicy... (In our summer capital...) Ludwik Szczepański's satire on Young Poland tourists in the Tatras}

\section{Summary}

In the article the author analyses a slightly forgotten satirical novel by Ludwik Szczepański, W naszej letniej stolicy, czyli przygoda rejenta Nowakowskiego w Zakopanem (In our summer capital or the adventure of Nowakowski, a notary, in Zakopane) (1904, published under the pseudonym Wincenty Ogórek). She tackles three topics: 
1. Placement of the novel in the context of other Young Poland period works referring to the discovery of Zakopane as an ideal place for summer holidays by Poles from various parts of the partitioned country, especially by residents of Kraków or Warsaw. In the first two parts of the article the author presents an outline of the plot and then discusses the topography of Zakopane and its environs, brilliantly depicted by Żeromski.

2. The subchapter "...this Zakopane train is especially full of nice, friendly women..." contains a detailed analysis of direct and indirect (linguistic, stylistic, personal and cultural) references to Kazimierz Przerwa-Tetmajer, whose satirical anti-portrait as the poet Przerwański, is included in the novel by Szczepański.

3. In the last part of the article the author points to those features of Szczepański's novel which make it possible to describe it as a "resort novel". In addition, she refers to other titles of literary works from the Young Poland period, which fit in with the proposed literary convention. The term "resort novel" refers to Jacek Kolbuszewski's earlier concept of "boarding house novel".

In the conclusion the author points to the possibility of reinterpreting numerous "resort novels" from the Young Poland period with the help of the latest tools used in the description and analysis of various phenomena relating to tourism understood as a subject of research in the humanities.

Góry najlepiej z dołu oglądać [...]

I po co, pytam się, męczyć, drapiąc się do góry, kiedy i tak zejść trzeba? ${ }^{1}$

Ludwik Szczepański (1872-1954) jest dziś pamiętany głównie jako założyciel krakowskiego „Życia” (1897) i twórca wiersza Żegluga, którym na stałe wpisał się w antologie młodopolskiej poezji dekadenckiej ${ }^{2}$. Zarówno ten, jak i inne wczesne utwory Szczepańskiego, a przede wszystkim wydawany przez niego dwutygodnik satyryczny „Urwisz” (1898), sygnalizują krytyczne spojrzenie poety na otaczającą go rzeczywistość. O ostatnim z wymienionych tytułów pisał Andrzej Zyga:

Powstał on w wyniku rozbudowania w „Życiu” rubryki satyryczno-polemicznej „Echa” i pojawienia się satyrycznych, ,niedekadenckich” wierszy Szczepańskiego i Tetmajera. Z „Urwiszem” [...] związała się większość krakowskich współpracowników „Życia”, w wierszach, felietonach i karykaturach dając upust swej pasji krytyczno-polemicznej [... $]^{3}$.

Z czasem ta „pasja krytyczno-polemiczna” Szczepańskiego wyostrzy się na tyle, żeby na przełomie lat 1902 i 1903 zrodzić powieść opisującą wakacje krakowsko-warszawskiego towarzystwa w Tatrach. Publikacja książki $W$ naszej letniej stolicy, czyli przygoda rejenta Nowakowskiego w Zakopanem — prozatorskiego

1 [L. Szczepański] W. Ogórek, Wnaszej letniej stolicy, czyli przygody rejenta Nowakowskiego w Zakopanem, Kraków 1904, s. 22-23.

2 Por. J. Bajda, Poezja drugiej połowy XIX wieku (pozytywizm-Młoda Polska). Antologia, red. J. Kolbuszewski, Wrocław 2007, s. 393; pierwodruk utworu: L. Szczepański, Srebrne noce. Lunatica, Wiedeń 1897. Wiersz otwiera znany incipit: „Wśród oceanu czarnej kawy / Płynę do Wyspy Ukojenia".

3 A. Zyga, Krakowskie „Życie” pod redakcją Ludwika Szczepańskiego (1897-1898). Cz. 2, „Kwartalnik Historii Prasy Polskiej” 25, 1986, nr 4, s. 58. 
debiutu pisarza, wydanego pod pseudonimem Wincenty Ogórek — została odnotowana przez ówczesnego recenzenta:

Z pozoru wygląda to na satyrę życia towarzyskiego na letnisku w Zakopanym [sic!], bardzo zresztą nieumiejętną i pełną przesady i karykaturalności. W samej zaś rzeczy jest to brzydki paszkwil na jednego z pisarzy współczesnych, więcej posiadającego talentu w jednym pociągnięciu pióra, niż cała kupa takich kiepskich ogórków. Szczególnego rodzaju sport! ${ }^{4}$

„Nowy Korbut” podaje to jedno odniesienie do powieści w młodopolskiej prasie $^{5}$. Nie wspominają o niej współczesne podręczniki historii literatury, a tytuł pojawia się zaledwie w kilku z licznych opracowań poświęconych młodopolskiemu widzeniu $\operatorname{Tatr}^{6}$. Trudno się temu dziwić, bo literacko jest to rzecz słaba, a wizerunek owego ,jednego z pisarzy współczesnych”, o którym wspominał Henryk Galle, to rzeczywiście — wypada się zgodzić z recenzentem — niewybredny paszkwil.

Niemniej jednak powieść warta jest odczytania zarówno z perspektywy kulturowej, jak i stricte filologicznej z kilku powodów. Po pierwsze, Szczepański, znając tatrzańskie i zakopiańskie realia, umieścił swoich bohaterów w rzeczywistej topografii rejonu: opisał warunki przestrzenne i bytowe Zakopanego przełomu stuleci oraz wprowadził do powieści najbardziej lubiane przez młodopolskich turystów instytucje kulturalne, punkty hotelowe i gastronomiczne miejscowości. To kolejne literackie potwierdzenie istnienia kultowych miejsc na przełomie wieków w Zakopanem i jego najbliższej okolicy, obowiązkowych do odwiedzenia przez letników i kuracjuszy.

Po wtóre, warto przyjrzeć się odniesieniom do wzmiankowanego „pisarza współczesnego", z którą to postacią autor wprowadza do powieści pewien rodzaj letniskowej obyczajowości, typowej dla niektórych bywalców zakopiańskich pensjonatów. Jest nim swoisty erotyzm kurortowy, pełen niebezpiecznych zwrotów akcji, które świadomie podejmuje zarówno literat, jak i tytułowy rejent Nowakowski. Pojawia się tu również konieczność odwołania do perspektywy filologicznej ze względu na jawne odniesienia do doskonale rozpoznawalnego na przełomie stuleci języka i stylu wzmiankowanego literata.

W końcu też wszystkie dające się wskazać w powieści Szczepańskiego okoliczności pobytu bohaterów w „naszej letniej stolicy” można odnaleźć także w kilku innych młodopolskich powieściach. Pozwala to na podjęcie próby kodyfikacji

${ }^{4}$ H. Galle, Ogórek Wincenty. W naszej letniej stolicy, czyli przygody rejenta Nowakowskiego w Zakopanem, „Książka” 5, 1905, nr 5, s. 187.

5 Szczepański Ludwik, [hasło w:] Literatura pozytywizmu i Młodej Polski, „Bibliografia Literatury Polskiej »Nowy Korbut«" 15, s. 636-639.

6 Por. np. J. Kolbuszewski, Tatry w literaturze polskiej, cz. I (1805-1888), cz. II (1889-1939), Kraków 1982, s. 440, 449; idem, Tatry i górale w literaturze polskiej. Antologia, Wrocław 1992, s. 368; idem, Od Pigalle po Kresy. Krajobrazy literatury popularnej, Wrocław 1994, s. 146; J. Majda, Młodopolskie Tatry literackie, Kraków 1989, s. 184, 186, 188, 225. Fragmenty powieści przywołuje Roman Hennel w antologii Kpiarze pod Giewontem, Warszawa 1987, s. 78-101. 
wyznaczników kolejnego typu młodopolskiej powieści obyczajowej — przez Jacka Kolbuszewskiego nazywanej ,powieścią pensjonatową", tutaj zaś wstępnie określanej mianem „powieści kurortowej”.

\section{Schemat fabularny}

Konstrukcja fabuły powieści jest prosta: podróż do Zakopanego — pobyt na letnisku, ze szczególnym uwzględnieniem perypetii towarzysko-romansowych powrót do domu. Równie banalna jest treść wypełniająca ten trójczłonowy schemat: grupa turystów z Warszawy i Krakowa wyjeżdża na kilka tygodni do Zakopanego. Do bohaterów należą panowie radcy Smoł i Mglej oraz rejent Erazm Nowakowski z Krakowa, rodzina państwa Małkowskich z Warszawy (pan domu, jego żona oraz dorastająca córa Dzidzi) i w końcu powszechnie znany pisarz. Wszyscy spotykają się w pociągu relacji Kraków-Zakopane — to fakt istotny, bo - jak odnotowują badacze turystyki w rejonie Tatr — w dużej mierze zawdzięczamy mu nagły rozwój tego zjawiska:

Spośród wsi na terenie Podtatrza najszybciej rozwijało się Zakopane, które z czasem stało się dużym ośrodkiem turystycznym, letniskowym i uzdrowiskowym. Przyczyniło się tego doprowadzenie w 1884 r. linii kolejowej z Krakowa do Chabówki i w 1899 r. do samego Zakopanego. Dzięki niej skrócił się znacznie czas podróży z Krakowa, która wcześniej góralskimi furmankami trwała $2 \mathrm{dni}^{8}$.

Po dotarciu na miejsce letnicy rozpierzchają się w poszukiwaniu kwater. Kolejne rozdziały to nieustanne zabiegi rejenta i poety o względy panny Dzidzi. Pierwszy z nich pisze miłosny wiersz i skrupulatnie podlicza w kajecie wydatki na cukierki i kwiaty, drugi - nie mogąc pojąć, dlaczego panna tak długo mu się opiera - poszukuje środka kompromitującego rywala. Stanie się nim ów niefrasobliwie zgubiony przez rejenta kajet $\mathrm{z}$ zapiskami, który pewny siebie pisarz niecnie wykorzysta, prezentując go pani Małkowskiej i jej córce. Triumf nie trwa jednak długo, ponieważ panna Dzidzi podsłuchuje umizgi młodzieńca do góralskiej pokojówki Milci Czubkówny, co doprowadza ją do histerii i pewności, że pozostawiony w Warszawie niejaki pan Karol nigdy by tak nie postąpił. Literat, nie godząc się z bezpardonową odprawą, mści się okrutnie. Powstaje przydługa i pełna złośliwości satyra Panna Dzidzi, czyli Anioł zniszczenia, natychmiast wysłana do „Kuriera Warszawskiego” z nadzieją, że Wolff zapłaci po 20 kopiejek od linijki. Na kolejnych kartach powieści literat próbuje pocieszyć się flirtem z panią

7 Jacek Kolbuszewski wprowadził ten termin, omawiając typ polskiej powieści obyczajowej sytuowanej na dalekim pograniczu niemieckiego Bergroman; por. idem, Od Pigalle po Kresy..., s. 119-165 n. (rozdz. Tatrzańska gra miłości i śmierci; tu przykłady realizacji gatunku Bergroman oraz polskiej ,powieści pensjonatowej”).

${ }^{8}$ W. Kurek, Historia turystyki w Polsce, [w:] Turystyka, red. W. Kurek, Warszawa 2007, s. 60. 
Dally, zakończonym głośnym policzkiem... Na szczęście, czas kanikuły dobiega końca. Autor, bagatelizując niedoszłe erotyczne smaczki związane z wątkiem poety, powraca do tytułowej postaci rejenta Nowakowskiego, podsumowując jego pobyt w Zakopanem słowami:

Jest w domu, jest u siebie! Skończyły się niewygody, brak porządku, skończyło się próżniactwo. Zacznie się znowu życie porządne, systematyczne, pracowite! Dość miał już tej naszej letniej stolicy! ${ }^{9}$

\section{Topografia Tatr i Zakopanego}

Ludwik Szczepański, choć dziesięć lat swojej wczesnej młodości (1880-1890) spędził za sprawą posady ojca w Wiedniu, często przyjeżdżał do Zakopanego i w Tatry. Uprawiał turystykę, zdarzało się, że wychodził w wysokie góry, pasjonował się myślistwem ${ }^{10}$. Dobrze zatem znał opisywaną w powieści przestrzeń i wszelkie zwyczaje, które towarzyszyły najpierw samej podróży do Zakopanego, a następnie na kilka miesięcy opanowywały letnią stolicę Polski ${ }^{11}$. Jest to czytelne od pierwszych stron powieści, kiedy narrator wprowadza swoich bohaterów do wagonu i z przymrużeniem oka opisuje panującą w pociągu atmosferę oraz stosy przewożonych bagaży:

Ścisk i zamęt z każdą chwilą stawały się większe. Stosy kufrów i koszów piętrzyły się na dworcu [...]. Były tam wanny, opakowane ręką zapobiegliwej służącej w papier i szmaty, składane krzesła ogrodowe, obwiązane

9 W. Ogórek, op. cit., s. 120. We wszystkich cytowanych w artykule fragmentach powieści uwspółcześniono ortografię i interpunkcję.

10 Por. M. Wulczyńska, Szczepański Ludwik, [hasło w:] Polski Stownik Biograficzny, red. A. Romanowski, t. 47, Warszawa-Kraków 2010-2011, s. 343-349.

11 Ze względu na warunki bytowe proponowane gościom przez górali oraz na brak odpowiedniej infrastruktury Zakopane w okresie zaborów było głównie „letnią stolicą”. „Zimową stolicą” (jak współcześnie) stało się wraz z odzyskaniem przez Polskę niepodległości. Dopiero wówczas zaczęła powstawać infrastruktura hotelowa oraz nastąpił rozwój sportów zimowych; por. Z. Moździerz, Architektura i rozwój przestrzenny Zakopanego 1600-2013, Zakopane 2013, zwł. rozdz. Letnia stolica Polski (1891-1918). Styl zakopiański, eklektyzm, wczesny modernizm, s. 163-250; Zimowa stolica Polski (1918-1939). Historyzm lat 20., pólmodernizm, funkcjonalizm, regionalizm, s. 251-349. Nie oznacza to jednak, że na przełomie XIX i XX wieku Zakopane nie było rozpoznawane także zimą. Fakt ten został odnotowany w literaturze, między innymi w powieści Gabrieli Zapolskiej Sezonowa miłość. Interesujące byłoby porównanie opisu „letniej stolicy” z perspektywy doskonale ją znającego Szczepańskiego z opisami tych okolic w książce Zapolskiej, która wydając powieść w 1904 roku, była ponoć zaledwie po jednym pobycie w Zakopanem; por. J. Czachowska, Gabriela Zapolska. Monografia bio-bibliograficzna, Kraków 1966, s. 302. Inne ustalenia podaje Krystyna Heska-Kwaśniewicz, dowodząc, że Zapolska po raz pierwszy znalazła się w Tatrach w 1895 roku, żeby powrócić tam (z powodów leczniczych) w kwietniu 1903 roku; por. eadem, Lepsze sto Giewontów, Liliowych i Mnichów niż jedna blondynka o niebieskich oczach. Sezonowa miłość z Tatrami w tle, [w:] Pejzaże kultury. Prace ofiarowane Profesorowi Jackowi Kolbuszewskiemu w 65. rocznicę Jego urodzin, red. W. Dynak, M. Ursel, Wrocław 2005, s. 363. 
sznurkiem, cebrzyki, konwie, kosze, kufry, stare walizy skórzane, konie drewniane dla dzieci, rowery, hamaki, w ogóle wszystko, „co się może przydać" członkom rodziny udającej się na letni pobyt w jeden z naszych uroczych zakątków, w letnie stolice i perły tatrzańskie ${ }^{12}$.

Oczekiwanie na odjazd pociągu upływa panom na grze w karty, a sama droga na pierwszych próbach oczarowania niewinnej Dzidzi, jedynego w przedziale obiektu godnego zainteresowania. Równocześnie jednak co jakiś czas narrator przypomina czytelnikowi topograficzne realia podróży. Pasażerowie najpierw dojeżdżają do Chabówki, następnie mijają Szaflary. Za oknami wagonu pojawia się rozpoznany przez pannę Dzidzię Giewont, który natychmiast staje się pretekstem dla znakomicie znającego góry poety do opowieści o śpiących rycerzach. I jest to w zasadzie jeden z dwóch szczytów, na który w całej powieści raczą spojrzeć oczywiście z dołu — nasi bohaterowie. Drugim jest Gubałówka. Ostatnią górską atrakcją stanie się wyczerpująca wyprawa części towarzystwa (wraz z góralskimi przewodnikami) furą do Doliny Kościeliskiej. Szczepański opisuje trasę przejazdu, odwzorowując zarówno mijane widoki, jak i wszelkie niedogodności jednodniowej wycieczki, czyniąc z niej obowiązkowy punkt pobytu na letnisku:

Fura przejechała już długą ulicę Kościeliską i Skibówki i toczyła się dalej gościńcem nieźle utrzymanym [...]. Za Sanatorium droga się już psuje i jest taką prawdziwą góralsko-polską drogą, pełną błota, wybojów. [...] Wreszcie [...] droga skręca się nagle na lewo — a oczom turysty ukazują się dwie skały — Brama Kantaka - u wejścia do doliny, a dalej zamyka widnokrąg wyniosły rozłożysty grzbiet Bystrej [...]. Przejeżdżamy przez Bramę, i fura toczy się dalej wzdłuż potoku [...] przejeżdżamy przez most, koło lip stuletnich, koło kapliczki w lesie — wreszcie stoki skał rozstępują się - fura zajeżdża na obszerną łąkę, na której stoi gospoda. Stało tam już kilka fur góralskich, co przywiozły gości ${ }^{13}$.

Na tym kończą się dla bohaterów zarówno te wysokie, jak i te bardziej przystępne Tatry. Szczególnie że — jak mawiał pan Małkowski — ,Jedziemy do Zakopanego na odpoczynek, a nie po to, żeby chodzić po jakichś wertepach!"14. Dlatego też zdecydowanie częściej snujemy się wraz z bohaterami po Krupówkach, od niechcenia zachodząc do słynnej Cukierni Zakopiańskiej Waleriana Płonki, gdzie poeta ,upowity w ciszę, melancholię i tęsknotę, siedział po obiedzie na werandzie [...] i pił herbatę ze śmietanką"15, spędzamy czas na werandzie ekskluzywnego Hotelu Morskie Oko bądź bywamy w jego sali teatralnej tudzież w Zakładzie Wodoleczniczym doktora Chramca na reunionach obowiązkowych dla letniskowego monde’u, poznajemy niezliczone pensjonaty, których słoneczne nazwy miały

\footnotetext{
12 W. Ogórek, op. cit., s. 8.

13 Ibidem, s. 110-111.

14 Ibidem, s. 22.

15 Ibidem, s. 56.
} 
przyciągać gości: „Przedświt”, „Promienna”, „Przejasna”, „Świetlista”. Pod nieobecność w topografii Zakopanego Dworca Tatrzańskiego, uznawanego za pierwszy zakopiański Dom Kultury ${ }^{16}$, Szczepański pośród turystyczno-towarzyskich atrakcji wymienia również nieco nieoczekiwanie dworzec kolejowy - miejsce spotkań, pożegnań i swoisty kurortowy deptak, na którym można, a nawet należy się pokazać:

Na peronie zbiera się ciżba letników zakopiańskich, którzy tęsknymi oczami wpatrują się w nadchodzący pociąg. Głównym bowiem punktem wycieczek i spacerów jest, obok „Doliny Płonki”, dworzec. Kto żyw dąży tam po południu, oczekując cierpliwie nadejścia zawsze spóźnionego pociągu: żony, stęsknione za mężami, babcie, ciocie, Don Żuani zakopiańscy w kostiumach do tenisa, służące, guwernantki z dziećmi, gazdowie i woźnice, oczekujący swoich zamówionych gości — wszystko to spieszy na dworzec ${ }^{17}$.

Autor kpi także z ówczesnej mody na styl zakopiański, a w zasadzie z estetycznej nieświadomości turystów i chęci kojarzenia z nim wszystkiego, na co można się było natknąć w Zakopanem. Szczególnie podkreśla bytowe niedogodności, z którymi przyszło się mierzyć kuracjuszom:

Pani Małkowska z panną Dzidzi, nie czekając na wyładowanie bagażów, pospieszyły czym prędzej do willi, aby zwiedzić swe apartamenta. Weszły i patrzyły osłupiałe: w pierwszej izbie stały dwa łóżka, stół biały, stołek i stolik nocny; w drugim pokoju stały trzy łóżka, jeden stołek i szafa; w trzecim pokoju stały znowu dwa łóżka i mały stołeczek, używany przy podoju. Zresztą izby były puste, ściany gołe, a łóżka wypełniały tylko sienniki.

Pani Małkowska, widząc tę pustkę, załamała ręce [...].

— Moje dziecko, to... to jest takie proste urządzenia. Widzisz, teraz nawet $\mathrm{w}$ modzie jest styl zakopiański... ${ }^{18}$

Szczepański nie zapomniał również o charakterystycznej werandzie, bez której nie mogła obejść się żadna willa w stylu zakopiańskim, choć przywoływał tę przestrzeń nie jako typowy element konstrukcji budynku, a jedynie jako miejsce picia porannej kawy bądź obserwacji tłumu przemieszczającego się po Krupówkach. Szczególnie zaintrygowało go natchnienie, które pewnego ranka spłynęło na

16 Usytuowany przy Krupówkach Dworzec Tatrzański (arch. Karol Zaremba) powstał w latach 1880-1882 z inicjatywy Walerego Eljasza. Po pożarze w 1900 roku nowy budynek (arch. Wandalin Beringer) otwarto dopiero 1 lipca 1903 roku. W Dworcu Tatrzańskim odbywała się większość imprez kulturalnych Zakopanego; por. M. Pinkwart, Zakopiańskim szlakiem Walerego i Stanisława Eljaszów, Warszawa-Kraków 1988, s. 67-69.

17 W. Ogórek, op. cit., s. 28.

18 Ibidem, s. 45-46. 
takiej właśnie werandzie na rejenta Nowakowskiego. Zakochany w pannie Dzidzi składał bolesne dla ucha czytelnika rymy:

Na ławce siedzieli oboje,

On i ona, tak we dwoje,

A krzak zielony był trzeci,

I trochę rozmaitych rupieci ${ }^{19}$.

Nie mogły się te strofy, choć spisywane złotym ołówkiem rejenta, mierzyć z mistrzostwem pióra „współczesnego poety”.

\section{„[W] tym zakopiańskim pociągu specjalnie roi się od kobietek miłych, sympatycznych"}

Znamienne jest, że cytowane słowa są jednymi z pierwszych, jakie zdołał wypowiedzieć rejent Nowakowski po wejściu do przedziału pociągu relacji Kraków-Zakopane. Od razu też Szczepański dosadnie precyzuje, w jakim celu rejent wybiera się do letniej stolicy:

Bo trzeba panom wiedzieć, że w tym zakopiańskim pociągu specjalnie roi się od kobietek miłych, sympatycznych. I to wszystko poubierane tak lekko, luźno, w batysty, jedwabie, w fulary. Zaraz się widzi, że to, co mają, to nie jest $\mathrm{z}$ waty.

- Gdzie to pan wszystko dostrzegł, tego nie wiem. Ja bo widzę tu tylko służące i bony z manatkami — rzekł radca Smoł.

— A cóż to? Taka fertyczna służąca nie może być ładna? — zaśmiał się rejent.

— Gdybyśmy byli teraz w marcu, tobym się panu nie dziwił.

- Za pozwoleniem. Wam panowie dobrze żartować, jedziecie sobie do żony, do dzieci... Ale człowiek samotny jak ja musi się przecie gdzieś ogrzać, przytulić... ${ }^{20}$

Zaraz potem następuje pierwsze spotkanie z pisarzem. Czytelnikowi nie pozostawia się nawet cienia niepewności co do postaci spóźnionego pasażera:

Nowy podróżny, młody człowiek, średniego wzrostu, blady, z twarzą bez wyrazu, miał na sobie francuską pelerynę, miękki kapelusz; spod peleryny wyglądała $\mathrm{z}$ fantazją zawiązana krawatka. [...]

- Pozwoli pan, że wobec tych konkurencyjnych poezyj wielce szanownego rejenta, i ja się przedstawię — Przerwański.

19 Ibidem, s. 55.

20 Ibidem, s. 7. 
— Mamo, mamo, pan Przerwański jedzie z nami... Jakie to szczęście, że z prawdziwym poetą jedziemy! $!^{21}$

W tej chwili rozpoczyna się ciągnąca się przez całą powieść rywalizacja między „człowiekiem samotnym” a wiecznie pełnym namiętności poetą o względy panny Dzidzi. Kazimierz Przerwa-Tetmajer, którego antyportret kreuje Szczepański, próbuje też zdobyć Milcię Czubkównę, a w końcu panią Dally. We wszystkich miłosnych wyzwaniach bohaterowie ponoszą porażkę. Samo współzawodnictwo amantów szybko jednak blednie w porównaniu z niewybrednymi chwytami, których używa autor, żeby obnażyć „,prawdziwe” oblicze Tetmajera. Odczytujemy je w dwóch wymiarach: biograficznym, bezpośrednio odwołującym się do wydarzeń z życia poety, oraz językowym, kiedy Szczepański stylizuje zarówno narrację, opisy, jak i całe fragmenty poetyckie, posługując się rytmizacją znaną z Tetmajerowskiej poezji, cytując ulubione wyrażenia i zwroty poety czy wprowadzając nastrój charakterystyczny dla jego obrazowania.

Szczepański, wbrew przywoływanej na początku jednoznacznej recenzji Henryka Gallego, poradził sobie z tym zadaniem. Dobrze znał nie tylko samego Tetmajera, z którym współpracował najpierw w krakowskim „Życiu”, a później w „Ilustracji Polskiej”, ale i jego twórczość, którą chętnie drukował22 i z której wiele czerpał dla swoich własnych rymów, posiadając - jak zarzucała mu krytyka - „bardzo bluszczowatą naturę"23. Tak negatywne potraktowanie bliskiego współpracownika, którego sam uznawał za „przywódcę najmłodszego pokolenia poetów"24, sugeruje istnienie jakiegoś konfliktu, lecz ani dość dobrze już rozpoznana biografia Tetmajera ${ }^{25}$, ani krótkie noty biograficzne Szczepańskiego nie przynoszą odpowiedzi, na czym miałby on polegać ${ }^{26}$.

Na niemal każdej stronie powieści czytelny jest pełen sarkazmu stosunek do przekonań ideowych, wyznaczników estetycznych Tetmajera, jego sposobu bycia. W wypowiedziach Przerwańskiego, a także w komentarzach odnarratorskich pojawiają się sugestie dotyczące stosunku poety do kobiet, tworzenia wokół siebie aury wyjątkowości, pewności swojego talentu, tematów podejmowanych w wierszach, ulubionych wyrażeń i zwrotów. Wszystko karykaturalnie wyolbrzymione i zdeformowane, świadczące o bezpardonowym wykorzystaniu zażyłości Szczepańskiego i Tetmajera. Trzeba jednak przyznać, że z prawdziwą wirtuozerią satyrycznego

21 Ibidem, s. 11, 14.

22 „Obfitością publikowanych w »Życiu« liryków przewyższał pozostałych współpracujących z nim poetów" - A. Zyga, op. cit., s. 48.

${ }^{23}$ Por. W.S., Ludwik Szczepański. Srebrne noce, „Tygodnik Ilustrowany” 1897, nr 31, s. 616. Recenzent wytykał Szczepańskiemu bezpośrednie nawiązania między innymi do poezji Juliusza Słowackiego i właśnie Kazimierza Przerwy-Tetmajera, pisząc: „Język zupełnie czysty, ale brak mu siły i świeżości; znać tu silne wpływy postronne, zwłaszcza Słowackiego (Nieznajomej dalekiej), Tetmajera (Thule) i wielu innych".

${ }^{24}$ A. Zyga, op. cit., s. 48.

25 Por. K. Jabłońska, Kazimierz Tetmajer. Próba biografii, Kraków 1969; T. Januszewski, Kazimierz Przerwa-Tetmajer, Warszawa 2015.

26 Por. M. Wulczyńska, op. cit.; Szczepański Ludwik, s. 636-639. 
pióra autor oddaje zróżnicowany język, jakim przemawiał Tetmajer do niewinnej panny Dzidzi, prostej góralskiej dziewczyny Milci i dojrzałej pani Dally, poczynając od błękitnych uniesień podszytych erotyzmem, poprzez jednoznaczną propozycję kierowaną w stronę młodej góralki (wygłaszaną gwarą góralską), aż po wybuch afektu wobec doświadczonej damy z warszawskiego monde'u:

Poeta usiadł u jej nóg.

- Panno Dzidzi — szeptał — gdziekolwiek pani stąpi swym maleńkim pantofelkiem, kwiecie wyrasta. Widzi pani, tu, pod nóżką pani, błękitny wyrósł kwiat. Przycisnęła go pani, siadając, ale to mu było widać bardzo przyjemne, bo podniósł zaraz kornie pochyloną główkę.

— To dzwonek - rzekła panna Dzidzi.

— Tak jest, dzwonek błękitny. A co dzwoni błękitny dzwonek? Dzwoni cichutko pieśń chwały i szczęścia na cześć drobnych nóżek pani. Dzwoni: ,„panna Dzidzi ma maleńkie nóżki w jedwabnych, czarnych pończoszkach. $\mathrm{O}$, móc pieścić maleńkie nóżki, które stąpają po kwiatach błękitnych..." 27 .

— [...] Ale przyjść mozes — i objął ją w pół, że zaraz ogromna lubość rozlała się jej po ciele. - Przyjdziesz po tych tańcach? Pokazem ci takom książkę, com ją napisał o Janosiku i o juhasach zbójnikach ${ }^{28}$.

- Ach, pani szydzi, pani Dally! I pani może szydzić wobec mej szczerości? O, gdybyś pani wiedziała, jak ja tęsknię i czekam...

- Czegóż pan czeka?

- Czego? Czy ja wiem? Słońca, burzy, gromu... Słońca, które by we mnie rozpaliło żar rozkoszy; burzy, która by mnie szałem wstrząsnęła; gromu, który uderzając we mnie, rozpętałby zarazem całą moc siły piorunowej ducha... Kobiety czekam, pani! Kobiety! Nie będę słów swoich maskował, mówię do pani szczerze. O Dally, ty jesteś tą kobietą słońcem, kobietą burzą, gromem. Czyż nie znam twej duszy? Możesz być słońcem i burzą! Nie jesteś stworzona do życia takiego, jakiem żyją setki kobiet bez serc, bez duszy, tyś jest stworzona na kochankę! Skarby serca twego ja odkryję i wyzwolę, o Dally, rozkoszy moja!

I poeta, klęknąwszy przed oszołomioną panią Dally, począł rękę jej okrywać pocałunkami, następnie pochwycił ją silnie w objęcia, zgodnie z systemem: sempre avanti...29

W innym miejscu Szczepański przywołuje artystyczne zainteresowania Tetmajera, również wykorzystywane do oczarowywania panny Dzidzi. W wypo-

27 W. Ogórek, op. cit., s. 63-64.

28 Ibidem, s. 86.

${ }^{29}$ Ibidem, s. 116-117. 
wiedź poety wplatane są zwroty niemalże bezpośrednio zaczerpnięte z jego wierszy, takie jak ,,bachiczne przegięcia"30 czy słynne „ciche zadumania"31:

- Gdy patrzę w oczy pani, to raz widzę w nich strzelające iskierki tajemnego żaru, a za chwilę znów rozlewa się w ich przeźroczu modrą falą ciche zadumanie... [...] Przedziwnym modelem, źródłem inspiracji byłaby pani dla malarzy! Tylko doprawdy nie wiem sam, który ze współczesnych mistrzów zdołałby stworzyć najlepszy portret pani... [...] Może Gandara, może Whistler? Albo znowu, gdyby panią malować w jakimś przegięciu bachicznym [wyr. — J.B.], byłaby pani pysznym typem dla Chéreta... [...]

Poeta wiedział, jak panny ,impressyonować" 32 .

Być może Szczepański pamiętał pochodzący z drugiej serii Poezji Tetmajera wiersz Pod wrażeniem, choć poeta nie odwoływał się w nim do malarzy dziewiętnastowiecznych, a dawnych mistrzów włoskich:

Kiedy na oczy srebrno-szafirowe spuści powieki i na wznak upadnie i leży miękko, sennie i bezwładnie, lekko schylając ku ramieniu głowę -

a płomień gazu, co nad nami płonie, półnagą stroi ją w światła i cienie, i ledwo znać jej białej piersi tchnienie widnej w przejrzystych koronek osłonie:

wówczas ma w sobie taki urok boski i takie dziwne piękności i czary, że, zda się, jakiś malował ją stary, anioły w duszy noszący mistrz włoski ${ }^{33}$.

Nie mogło zabraknąć w tych wszystkich kierowanych pod adresem Przerwańskiego złośliwościach „nirwany”34, „ciszy”, „tęsknot” i ,zamyśleń”, które towarzyszyły poecie niemal zawsze:

30 „Lubię, kiedy kobieta omdlewa w objęciu, / kiedy w lubieżnym zwisa przez ramię przegięciu" - K. Przerwa-Tetmajer, Lubię, kiedy kobieta..., [w:] idem, Poezje. Seria druga, t. 1, Warszawa 1924, s. 203.

31 „Po niebie i po lesie, / po łąk zielonych łanie, / przejrzyste zwiewne idzie / błękitne zadumanie" - K. Przerwa-Tetmajer, W lesie, [w:] idem, Poezje..., s. 215.

32 W. Ogórek, op. cit., s. 21.

${ }^{33}$ K. Przerwa-Tetmajer, Pod wrażeniem..., [w:] idem, Poezje..., s. 204.

34 Por. np. „Tęsknota za nirwaną, owiewająca słodkim czarem słowa »naszego znanego« poety, podrażniła prozaiczno-praktyczny umysł pani Małkowskiej” - W. Ogórek, op. cit., s. 16. 
poeta pozostał na werandzie sam, $\mathrm{z}$ duszą swoją upowitą w melancholię i zniechęcenie. Aby się rozerwać, wziął do ręki „Słowo Polskie". Natrafił niefortunnie na notatkę pana Bartoszewicza o poecie Iksińskim, autorze zbiorku nowych poezyj pod tytułem „Nenufary”, który to zbiorek nie podobał się panu Bartosz. Pan Bartosz. porównywał tony tego zbiorku z poezjami pana Przerwańskiego. Ubodło to srodze melancholijną duszę poety. Zażądał papieru i na trzech arkuszach wystosował sążnisty manifest do redakcji „Słowa Polskiego", oznajmiając, że będzie zmuszony zerwać stosunki z pismem, jeżeli melancholie poezji jego będą porównywane z jakimikolwiek innymi melancholiami.

Wygotowanie tego manifestu przyniosło mu pewną ulgę. Zaczem powoli duch jego otrząsał się z bolesnej zadumy i przyszło nań błękitne zamyślenie. I oto panna Dzidzi szła ku niemu, w rozkosznym przegięciu, przez wykroty puszczy dziewiczej, rojącej się od mastodontów przedpotopowych, żyraf i faunów [wyr. - J.B.]... ${ }^{35}$

To już nie tylko niemalże cytaty z Tetmajerowych wierszy ${ }^{36}$, ale też odwołania do realnych sytuacji, kiedy poeta słał słowa skarg do czasopism umieszczających jego nazwisko w niezadowalającym go kontekście ${ }^{37}$.

Należy jednak oddać sprawiedliwość, że Szczepański dosadnie wytyka także towarzyskie ,wystawianie" młodych panien przez ich matki, zawsze mające na uwadze możliwość znalezienia dla córki odpowiedniej partii. Z pewnością nie mógłby się nią stać wielokrotnie już w owym czasie matrymonialnie skompromitowany Tetmajer, ojciec kilkuletniego nieślubnego syna ${ }^{38}$, ale wszak nie on jeden bywał w Zakopanem. To swoiste targowisko próżności odbywało się w kilku miejscach regularnie wizy towanych przez turystów, a szczególnie podczas reunionów w Hotelu Morskie Oko. Pani Małkowska tak oto opisywała poecie męczące letniskowe obowiązki matki:

— Słyszałem, że państwo byliście na reunionie w „Morskim Oku”? pytał poeta.

35 Ibidem, s. 57-58.

${ }^{36}$ Przypomnijmy choćby słynne strofy pochodzące z cyklu Zamyślenia (II): „Melancholia, tęsknota, smutek, zniechęcenie / Są treścią mojej duszy...” (Poezje..., s. 249); fragment Preludiów: „Dusze błękitne, ciche, zamyślone” (Poezje..., s. 279); sonet Mastodonty: „Burza drzew! Pniów przepaście, ocean konarów, / Huragan życia, wulkan wzrostu i rozwoju, / Kaskady złotych liści, fontanny powoju, / Huk kwiatów pękających od słońca pożarów. // [...] // Błysnęło — to kły białe — na kształt morskiej fali, / Co się wzburzona naprzód bez pamięci wali, / Wybiegło z głębi puszczy stado mastodontów" (Poezje. Seria trzecia, t. 2, Warszawa 1924, s. 55).

${ }^{37} \mathrm{Na}$ ten temat pisałam w Poezja a sztuki piękne. O świadomości estetycznej i wyobraźni plastycznej Kazimierza Przerwy-Tetmajera, Warszawa 2003, s. 151.

38 Nieślubny syn poety, Kazimierz Stanisław Tetmajer, urodził się w 1901 roku; por. K. Jabłońska, op. cit., rozdz. Kazimierz Stanisław Tetmajer, s. 252-272; T. Januszewski, op. cit., s. 142. 
— Tak jest — i na wczorajszym koncercie także. Taka jestem zmęczona w tym Zakopanem, że nadzwyczajnie. Ledwośmy przyjechali, a po prostu spokoju nie mamy, wszędzie nas zapraszają. W rezultacie tutaj cała Warszawa przebywa i mamy tylu znajomych, że ani chwili odpoczynku. To raut na kościół, koncert na szpital, tombola na biednych, taka jestem zmęczona, że nóg nie czuję. Ale czegóż matka dla córki nie zrobi! ${ }^{39}$

Utwór Ludwika Szczepańskiego jest jedną z wielu młodopolskich powieści z kluczem, w których pojawia się postać Kazimierza Przerwy-Tetmajera jako bohatera, choć być może najzłośliwszą ${ }^{40}$. Współczesna perspektywa kulturowa każe jednak szczególnie docenić jej walory obyczajowe, wprowadzające czytelnika w krąg wydarzeń toczących się w hermetycznym środowisku tworzonym na zaledwie kilka wakacyjnych tygodni przez ludzi niemal zupełnie się nieznających, żyjących swoistym rytmem kurortowego życia.

\section{Młodopolska „powieść kurortowa”. Przyczynek do badań}

Podjęty przez Ludwika Szczepańskiego wątek pobytu młodopolskich turystów w letniej stolicy stał się tematem także kilku innych powieści przełomu XIX i XX wieku. Bodajże pierwszą próbą wprowadzenia bohaterów na tatrzańskie szczyty był szkic powieściowy Mieczysława Gwalberta Pawlikowskiego Baczmaha $(1898)^{41}$, rok później powstało opowiadanie Kazimierza Bartoszewicza Trzy dni $w$ Zakopanem ${ }^{42}$ (podobnie jak powieść Szczepańskiego wpisujące się w linię satyrycznego ujęcia uzdrowiskowych obyczajów), a w 1904 roku Sezonowa miłość Gabrieli Zapolskiej ${ }^{43}$.

39 W. Ogórek, op. cit., s. 61.

40 Por. np. A. Gruszecki, Pod Czerwonym Wirchem. Powieść współczesna, Warszawa 1913; T. Nalepiński, Wiatr halny, [w:] idem, Śpiewnik rozdarty, Warszawa [1914]; A. Strug, Zakopanoptikon, czyli kronika czterdziestu dziewięciu dni deszczowych w Zakopanem, Warszawa 1957 [pierwodruk w: „Wiek Nowy” 1913-1914].

41 M. Pawlikowski, Baczmaha. Szkic powieściowy, il. W. Przerwa-Tetmajer, WarszawaKraków 1898.

42 K. Bartoszewicz, Trzy dni w Zakopanem. Z notat emeryta przepisat..., Kraków 1899.

43 Kolbuszewski zwracał uwagę, że wbrew pozorom wcale nie było tych powieści zbyt wiele (idem, Tatry $w$ literaturze..., s. 438). Niewątpliwie jednak warto by ponownie odczytać w tym kontekście inne powieści i opowiadania (w układzie chronologicznym), takie jak: M. Parczewska, Tatrzański przewodnik, [w:] eadem, Obrazki, Obrazki 1893, s. 46-57; Z. Urbanowska, Róża bez kolców. Opowiadanie z niedawnej przeszłości osnute na tle przyrody tatrzańskiej z licznemi rycinami w tekście, Warszawa 1903; A. Strug, op. cit.; G. Dobrzańska, Zzakopiańskich tchnień, Poznań 1914; J. Żuławski, Laus feminae. Powieść współczesna, Warszawa 1914-1916, zwł. cz. 1. Powrót. Hennel pisze: „Kpinie z niewydarzonego bywalca uzdrowiska i kpinie z rzekomo nieudanego przewodnika-górala oraz gospodarza domu letniskowego, jak również krytyce lokalnego samorządu uzdrowiska poświęcone są dość liczne utwory XIX i początku XX wieku. Tę linię satyry uzdrowiskowej, obyczajowej, reprezentują zapomniane dziś pozycje: felieton Ludwika Zielińskiego z 1840 r. pt. Odwiedziny Gór Tatrzańskich, opowiadanko Kazimierza Bartoszewicza Trzy dni w Zakopanem 
Wszystkie te powieści i opowiadania łączy zainteresowanie Zakopanem i Tatrami jako miejscem wypoczynku polskich elit intelektualnych i artystycznych, ale też przedstawicieli warszawskiego i krakowskiego mieszczaństwa, ze szczególnym eksponowaniem obowiązkowego wątku romansowego, ubarwianiem rozlicznych zabiegów matrymonialnych oraz wyraźnym upodobaniem do podgrzewania skandali obyczajowych. Najczęściej akcja rozgrywa się w ściśle określonych i tłumnie odwiedzanych publicznych miejscach Zakopanego — to owa część „pensjonatowo-kurortowa”. Niekiedy jednak, jak w powieści Żuławskiego Laus feminae, bohaterowie ruszają $\mathrm{w}$ góry, na trasy znaczone konkretnymi tatrzańskimi szczytami, wprowadzając do powieści elementy turystyki górskiej.

Roman Hennel, analizując humorystyczne ujęcie tych tematów w literaturze polskiej, zwracał uwagę na kilka zasadniczych wątków przywoływanych w tym typie powieści. Pierwszym z nich jest „rozdźwięk pomiędzy ogromnym bagażem wymagań filistra, przyzwyczajonego do wygód i przyjemności kafejkowo-knajpianych, a nieprzygotowanym na to terenem prymitywnej przygody w surowej scenerii gór" ${ }^{44}$. Hennel pisał wprawdzie o młodopolskiej powieści satyrycznej, ale te same kwestie były też podejmowane chociażby przez Zapolską. Drugi wątek, mniej czytelny w powieści Szczepańskiego, lecz także sygnalizowany przez autorkę Sezonowej miłości, to góral awansujący do roli adoratora ${ }^{45}$. Są i inne cechy wspólne: wyprawa w Tatry na góralskiej furze, utyskiwanie na zakopiańskie drogi i tatrzańskie szlaki czy upodobanie górali do alkoholu, a szczególnie do butelek wyciąganych z sakwojaży kuracjuszy.

Obecnie turystyka coraz częściej staje się przedmiotem interdyscyplinarnych badań w obrębie nauk humanistycznych ${ }^{46}$. Pośród metod stosowanych do jej analizy i opisu podkreśla się znaczenie ujęcia antropologicznego, socjologicznego czy psychologicznego ${ }^{47}$. Każde z nich może stać się narzędziem ponownego odczytania młodopolskich ,powieści kurortowych”. W obszernym opracowaniu Turysty$k a$ pod redakcją Włodzimierza Kurka znajdujemy zasadnicze kategorie definiujące turystykę, które pozwoliłyby przyjrzeć się wybranym powieściom pod kątem realizacji tychże kategorii w przestrzeni literackiej. Autorzy wymieniają pośród nich: potrzeby i motywacje turystyczne; zagospodarowywanie przestrzeni tury-

(1889) [sic! opowiadanie Bartoszewicza pochodzi z 1899 roku — J.B.], Ludwika Szczepańskiego opowieść satyryczna W naszej letniej stolicy (1903) itd." — idem, Śmieszne Zakopane i zabawne góry, [w:] Kpiarze pod Giewontem, s. 16.

44 R. Hennel, Śmieszne Zakopane..., s. 16.

45 Ibidem, s. 17. Z pewnością nie była to sytuacja wyjątkowa, skoro nawet Boy uwiecznił ją w Kuplecie zakopiańskiego górala.

46 Por. m.in. (w układzie chronologicznym): W. Alejziak, Turystyka w obliczu XXI wieku, Kraków 2000; Turystyka w badaniach naukowych. Prace przyrodnicze i humanistyczne, red. J. Krupa, J. Biliński, Rzeszów 2006; Turystyka w naukach humanistycznych, red. R. Winiarski, Warszawa 2008; J. Marak, J. Wyrzykowski, Turystyka jako przedmiot interdyscyplinarnych badań naukowych, „Ekonomiczne Problemy Turystyki” 2009, nr 12, s. 165-180; L. Butowski, Turystyka jako dyscyplina nauki (artykut dyskusyjny), „Turyzm” 21, 2011, /1-2, s. 17-24 (tu: obszerna bibliografia przedmiotu).

47 Por. np. działy książki Turystyka w naukach humanistycznych. 
stycznych poprzez usługi hotelowe i gastronomiczne; różnorodność form turystyki; wpływ turystyki na rozwój danej przestrzeni ${ }^{48}$. Wszystkie te aspekty turystyki i kreowania przestrzeni kurortowej zostały uwzględnione w powieściach Szczepańskiego, Bartoszewicza, Pawlikowskiego czy Zapolskiej. Ich pogłębione badania z perspektywy kulturowej mogłyby się przyczynić do uwierzytelnienia znaczenia „kurortowej” odmiany młodopolskiej powieści obyczajowej, odwołującej się do równie istotnych dla przełomu stuleci zjawisk jak te podejmowane przez powieść o artystach, uznawaną za jedną z najbardziej reprezentatywnych dla epoki ${ }^{49}$.

\section{Bibliografia}

Alejziak W., Turystyka w obliczu wyzwań XXI wieku, Kraków 2000.

Bajda J., Poezja a sztuki piękne. O świadomości estetycznej i wyobraźni plastycznej Kazimierza Przerwy-Tetmajera, Warszawa 2003.

Bajda J., Poezja drugiej połowy XIX wieku (pozytywizm-Młoda Polska). Antologia, red. J. Kolbuszewski, Wrocław 2007.

Bartoszewicz K., Trzy dni w Zakopanem. Z notat emeryta przepisat..., Kraków 1899.

Butowski L., Turystyka jako dyscyplina nauki (artykut dyskusyjny), „Turyzm” 21, 2011, nr 1-2.

Czachowska J., Gabriela Zapolska. Monografia bio-bibliograficzna, Kraków 1966.

Dobrzańska G., Z zakopiańskich tchnień, Poznań 1914.

Galle H., Ogórek Wincenty. W naszej letniej stolicy, czyli przygody rejenta Nowakowskiego w Zakopanem, „Książka” 5, 1905, nr 5.

Gruszecki A., Pod Czerwonym Wirchem. Powiessć współczesna, Warszawa 1913.

Hennel R., Tatrami urzeczeni. Dawna turystyka w stowie i obrazie, Warszawa 1979.

Heska-Kwaśniewicz K., Lepsze sto Giewontów, Liliowych i Mnichów niż jedna blondynka o niebieskich oczach. Sezonowa miłość z Tatrami w tle, [w:] Pejzaże kultury. Prace ofiarowane Profesorowi Jackowi Kolbuszewskiemu w 65. rocznicę Jego urodzin, red. W. Dynak, M. Ursel, Wrocław 2005.

Jabłońska K., Kazimierz Tetmajer. Próba biografii, Kraków 1969.

Januszewski T., Kazimierz Przerwa-Tetmajer, Warszawa 2015.

Kolbuszewski J., Od Pigalle po Kresy. Krajobrazy literatury popularnej, Wrocław 1994.

Kolbuszewski J., Przestrzenie i krajobrazy, Wrocław 1994.

Kolbuszewski J., Tatry. Literacka tradycja motywu gór, Kraków 1995.

Kolbuszewski J., Tatry i górale w literaturze polskiej. Antologia, Wrocław 1992.

Kolbuszewski J., Tatry w literaturze polskiej, cz. I (1805-1888), cz. II (1889-1939), Kraków 1982.

Kolbuszewski J., Tatrzańska gra miłości i śmierci, Kraków 1975.

Kpiarze pod Giewontem, oprac. R. Hennel, Warszawa 1987.

Majda J., Literatura o Tatrach i Zakopanem (do roku 1918), Kraków 1981.

Majda J., Młodopolskie Tatry literackie, Kraków 1989.

Majda J., Styl zakopiański, Wrocław 1979.

Majda J., Tatrzańskim szlakiem literatury, Kraków 1982.

Majda J., Zakopiańskie centrum polszczyzny, Warszawa 1975.

Makowiecki A.Z., Młodopolski portret artysty, Warszawa 1971.

Marak J., Wyrzykowski J., Turystyka jako przedmiot interdyscyplinarnych badań naukowych, „Ekonomiczne Problemy Turystyki” 2009, nr 12.

48 Turystyka, passim.

49 Por. A.Z. Makowiecki, Młodopolski portret artysty, Warszawa 1971. 
Moździerz Z., Architektura i rozwój przestrzenny Zakopanego 1600-2013, Zakopane 2013.

Osobliwości i sensacje tatrzańskie, oprac. J. Kolbuszewski, Kraków 1977.

Nalepiński T., Wiatr halny, [w:] idem, Śpiewnik rozdarty, Warszawa [1914].

Ogórek W. [Szczepański L.], Wnaszej letniej stolicy, czyli przygody rejenta Nowakowskiego w Zakopanem, Kraków 1904.

Parczewska M., Tatrzański przewodnik, [w:] eadem, Obrazki, Obrazki 1893.

Pawlikowski M., Baczmaha. Szkic powieściowy, il. W. Przerwa-Tetmajer, Warszawa-Kraków 1898.

Pinkwart M., Zakopiańskim szlakiem Walerego i Stanisława Eljaszów, Warszawa-Kraków 1988.

Strug A., Zakopanoptikon, czyli kronika czterdziestu dziewięciu dni deszczowych w Zakopanem, Warszawa 1957.

Szczepański L., Srebrne noce. Lunatica, Wiedeń 1897.

Szczepański Ludwik, [hasło w:] Literatura pozytywizmu i Młodej Polski, „Bibliografia Literatury Polskiej »Nowy Korbut«" 15.

Tetmajer K. Przerwa, Poezje. Seria druga, Warszawa 1924.

Turystyka, red. W. Kurek, Warszawa 2007.

Turystyka w badaniach naukowych. Prace przyrodnicze i humanistyczne, red. J. Krupa, J. Biliński, Rzeszów 2006.

Turystyka w naukach humanistycznych, red. R. Winiarski, Warszawa 2008.

Urbanowska Z., Róża bez kolców. Opowiadanie z niedawnej przeszłości osnute na tle przyrody tatrzańskiej z licznemi rycinami w tekście, Warszawa 1903.

W.S., Ludwik Szczepański. Srebrne noce, „Tygodnik Ilustrowany” 1897, nr 31.

Wulczyńska M., Szczepański Ludwik, [hasło w:] Polski Słownik Biograficzny, red. A. Romanowski, t. 47, Warszawa-Kraków 2010-2011.

Zyga A., Krakowskie „Życie” pod redakcja Ludwika Szczepańskiego (1897-1898). Cz. 2, „Kwartalnik Historii Prasy Polskiej” 25, 1986, nr 4.

Żuławski J., Laus feminae. Powieść współczesna, Warszawa 1914-1916. 